

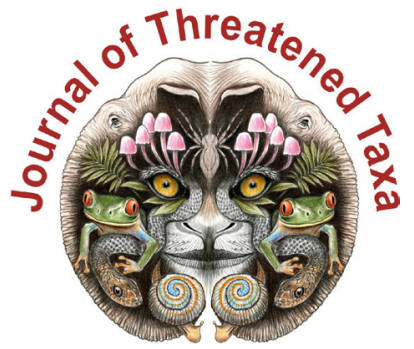

ISSN 0974-7907 (Online); ISSN $0974-7893$ (Print)

Publisher

Host

Wildlife Information Liaison Development Society

www.wild.zooreach.org

Zoo Outreach Organization www.zooreach.org

No. 12, Thiruvannamalai Nagar, Saravanampatti - Kalapatti Road, Saravanampatti, Coimbatore, Tamil Nadu 641035, India

Ph: +91 9385339863 | www.threatenedtaxa.org

Email: sanjay@threatenedtaxa.org

EDITORS

\section{Founder \& Chief Editor}

Dr. Sanjay Molur

Wildlife Information Liaison Development (WILD) Society \& Zoo Outreach Organization (ZOO),

12 Thiruvannamalai Nagar, Saravanampatti, Coimbatore, Tamil Nadu 641035, India

\section{Deputy Chief Editor}

Dr. Neelesh Dahanukar

Noida, Uttar Pradesh, India

\section{Managing Editor}

Mr. B. Ravichandran, WILD/ZOO, Coimbatore, India

\section{Associate Editors}

Dr. Mandar Paingankar, Government Science College Gadchiroli, Maharashtra 442605, India

Dr. Ulrike Streicher, Wildlife Veterinarian, Eugene, Oregon, USA

Ms. Priyanka Iyer, ZOO/WILD, Coimbatore, Tamil Nadu 641035, India

Dr. B.A. Daniel, ZOO/WILD, Coimbatore, Tamil Nadu 641035, India

\section{Editorial Board}

Dr. Russel Mittermeier

Executive Vice Chair, Conservation International, Arlington, Virginia 22202, USA

\section{Prof. Mewa Singh Ph.D., FASc, FNA, FNASc, FNAPsy}

Ramanna Fellow and Life-Long Distinguished Professor, Biopsychology Laboratory, and Institute of Excellence, University of Mysore, Mysuru, Karnataka 570006, India; Honorary Professor, Jawaharlal Nehru Centre for Advanced Scientific Research, Bangalore; and Adjunct Professor, National Institute of Advanced Studies, Bangalore

\section{Stephen D. Nash}

Scientific Illustrator, Conservation International, Dept. of Anatomical Sciences, Health Sciences Center, T-8, Room 045, Stony Brook University, Stony Brook, NY 11794-8081, USA

\section{Dr. Fred Pluthero}

Toronto, Canada

\section{Dr. Priya Davidar}

Sigur Nature Trust, Chadapatti, Mavinhalla PO, Nilgiris, Tamil Nadu 643223, India

\section{Dr. Martin Fisher}

Senior Associate Professor, Battcock Centre for Experimental Astrophysics, Cavendish

Laboratory, JJ Thomson Avenue, Cambridge CB3 OHE, UK

\section{Dr. John Fellowes}

Honorary Assistant Professor, The Kadoorie Institute, 8/F, T.T. Tsui Building, The University of Hong Kong, Pokfulam Road, Hong Kong

\section{Prof. Dr. Mirco Solé}

Universidade Estadual de Santa Cruz, Departamento de Ciências Biológicas, Vice-coordenado do Programa de Pós-Graduação em Zoologia, Rodovia Ilhéus/Itabuna, Km 16 (45662-000)

Salobrinho, Ilhéus - Bahia - Brasil

\section{Dr. Rajeev Raghavan}

Professor of Taxonomy, Kerala University of Fisheries \& Ocean Studies, Kochi, Kerala, India

\section{English Editors}

Mrs. Mira Bhojwani, Pune, India

Dr. Fred Pluthero, Toronto, Canad

Mr. P. Ilangovan, Chennai, India

Web Development

Mrs. Latha G. Ravikumar, ZOO/WILD, Coimbatore, India

\section{Typesetting}

Mr. Arul Jagadish, ZOO, Coimbatore, India

Mrs. Radhika, ZOO, Coimbatore, India

Mrs. Geetha, ZOO, Coimbatore India
Fundraising/Communications

Mrs. Payal B. Molur, Coimbatore, India

Subject Editors 2018-2020

Fungi

Dr. B. Shivaraju, Bengaluru, Karnataka, India

Dr. R.K. Verma, Tropical Forest Research Institute, Jabalpur, India

Dr. Vatsavaya S. Raju, Kakatiay University, Warangal, Andhra Pradesh, India

Dr. M. Krishnappa, Jnana Sahyadri, Kuvempu University, Shimoga, Karnataka, India

Dr. K.R. Sridhar, Mangalore University, Mangalagangotri, Mangalore, Karnataka, India

Dr. Gunjan Biswas, Vidyasagar University, Midnapore, West Bengal, India

\section{Plants}

Dr. G.P. Sinha, Botanical Survey of India, Allahabad, India

Dr. N.P. Balakrishnan, Ret. Joint Director, BSI, Coimbatore, India

Dr. Shonil Bhagwat, Open University and University of Oxford, UK

Prof. D.J. Bhat, Retd. Professor, Goa University, Goa, India

Dr. Ferdinando Boero, Università del Salento, Lecce, Italy

Dr. Dale R. Calder, Royal Ontaro Museum, Toronto, Ontario, Canada

Dr. Cleofas Cervancia, Univ. of Philippines Los Baños College Laguna, Philippines

Dr. F.B. Vincent Florens, University of Mauritius, Mauritius

Dr. Merlin Franco, Curtin University, Malaysia

Dr. V. Irudayaraj, St. Xavier's College, Palayamkottai, Tamil Nadu, India

Dr. B.S. Kholia, Botanical Survey of India, Gangtok, Sikkim, India

Dr. Pankaj Kumar, Kadoorie Farm and Botanic Garden Corporation, Hong Kong S.A.R., China

Dr. V. Sampath Kumar, Botanical Survey of India, Howrah, West Bengal, India

Dr. A.J. Solomon Raju, Andhra University, Visakhapatnam, India

Dr. Vijayasankar Raman, University of Mississippi, USA

Dr. B. Ravi Prasad Rao, Sri Krishnadevaraya University, Anantpur, India

Dr. K. Ravikumar, FRLHT, Bengaluru, Karnataka, India

Dr. Aparna Watve, Pune, Maharashtra, India

Dr. Qiang Liu, Xishuangbanna Tropical Botanical Garden, Yunnan, China

Dr. Noor Azhar Mohamed Shazili, Universiti Malaysia Terengganu, Kuala Terengganu, Malaysia

Dr. M.K. Vasudeva Rao, Shiv Ranjani Housing Society, Pune, Maharashtra, India

Prof. A.J. Solomon Raju, Andhra University, Visakhapatnam, India

Dr. Mandar Datar, Agharkar Research Institute, Pune, Maharashtra, India

Dr. M.K. Janarthanam, Goa University, Goa, India

Dr. K. Karthigeyan, Botanical Survey of India, India

Dr. Errol Vela, University of Montpellier, Montpellier, France

Dr. P. Lakshminarasimhan, Botanical Survey of India, Howrah, India

Dr. Larry R. Noblick, Montgomery Botanical Center, Miami, USA

Dr. K. Haridasan, Pallavur, Palakkad District, Kerala, India

Dr. Analinda Manila-Fajard, University of the Philippines Los Banos, Laguna, Philippines

Dr. P.A. Sinu, Central University of Kerala, Kasaragod, Kerala, India

Dr. Afroz Alam, Banasthali Vidyapith (accredited A grade by NAAC), Rajasthan, India

Dr. K.P. Rajesh, Zamorin's Guruvayurappan College, GA College PO, Kozhikode, Kerala, India

Dr. David E. Boufford, Harvard University Herbaria, Cambridge, MA 02138-2020, USA

Dr. Ritesh Kumar Choudhary, Agharkar Research Institute, Pune, Maharashtra, India

Dr. Navendu Page, Wildlife Institute of India, Chandrabani, Dehradun, Uttarakhand, India

\section{Invertebrates}

Dr. R.K. Avasthi, Rohtak University, Haryana, India

Dr. D.B. Bastawade, Maharashtra, India

Dr. Partha Pratim Bhattacharjee, Tripura University, Suryamaninagar, India

Dr. Kailash Chandra, Zoological Survey of India, Jabalpur, Madhya Pradesh, India

Dr. Ansie Dippenaar-Schoeman, University of Pretoria, Queenswood, South Africa

Dr. Rory Dow, National Museum of natural History Naturalis, The Netherlands

Dr. Brian Fisher, California Academy of Sciences, USA

Dr. Richard Gallon, llandudno, North Wales, LL30 1UP

Dr. Hemant V. Ghate, Modern College, Pune, India

Dr. M. Monwar Hossain, Jahangirnagar University, Dhaka, Bangladesh

Mr. Jatishwor Singh Irungbam, Biology Centre CAS, Branišovská, Czech Republic.

Dr. Ian J. Kitching, Natural History Museum, Cromwell Road, UK

Dr. George Mathew, Kerala Forest Research Institute, Peechi, India

For Focus, Scope, Aims, and Policies, visit https://threatenedtaxa.org/index.php/JoTT/aims_scope
For Article Submission Guidelines, visit https://threatenedtaxa.org/index.php/JoTT/about/submissions
For Policies against Scientific Misconduct, visit https://threatenedtaxa.org/index.php/JoTT/policies_various

continued on the back inside cover 


\title{
A geographical assessment of Chariganga and Arpara Beel (wetlands) of Nadia, West Bengal as a habitat of wetland birds
}

\author{
Mehedi Hasan Mandal ${ }^{1}$ (D), Arindam Roy ${ }^{2}$ (ID) \& Giyasuddin Siddique ${ }^{3}$ (iD) \\ ${ }^{1}$ Department of Geography, Krishnagar Govt. College, Krishnagar, Nadia, West Bengal 741101, India. \\ 2,3 Department of Geography, The University of Burdwan, Burdwan, West Bengal 713104, India. \\ ${ }^{1}$ hasanmhm86@gmail.com (corresponding author), ${ }^{2}$ a.roy.sc@gmail.com, ${ }^{3}$ gsbu2008@gmail.com
}

\begin{abstract}
The present study attempts to assess the impact of human intervention on the population, distribution, and habitat perspectives of the water birds found in and around Chariganga and Arpara 'Beel' wetlands, leftover channels of the River Bhagirathi. The point count method was adopted during field surveys conducted from April 2019 to March 2020. These wetlands are the natural habitats for 37 species of wetland birds belonging to 18 families and 11 orders, of which 26 species are residents, three are summer migrants, and eight are winter immigrants. The wetlands also harbour 10 bird species whose population is globally declining over the last few decades. Relative Diversity index unveils that among waterfowls Ardeidae is the dominant family. Species richness reaches its peak in winter, and is least during the monsoon. Empirical observation documented one Vulnerable (Greater Adjutant) and one Near Threatened (BlackHeaded Ibis) species residing on the banks and adjoining paddy fields. Indiscriminate extraction of wetland products by local people, along with agricultural expansion towards the waterfront of the wetlands, has deteriorated the health of those wetlands and threatened the existence of waterbirds, especially shorebirds. Populations of 22 species living in water edge areas has changed conspicuously owing to cultural and economic activities of neighboring human groups. We suggest improving the ecological balance of the wetlands and restraining further degradation through proper management to preserve avian diversity.
\end{abstract}

Keywords: Arpara Beel, Avian diversity, Chariganga, relative diversity index, species richness, water birds.

Citation: Mandal, M.H., A. Roy \& G. Siddique (2021). A geographical assessment of Chariganga and Arpara Beel (wetlands) of Nadia, West Bengal as a habitat of wetland birds. Journal of Threatened Taxa 13(13): 19964-19975. https://doi.org/10.11609/jott.6257.13.13.19964-19975

Copyright: (c) Mandal et al. 2021. Creative Commons Attribution 4.0 International License. JoTT allows unrestricted use, reproduction, and distribution of this article in any medium by providing adequate credit to the author(s) and the source of publication.

Funding: None.

Competing interests: The authors declare no competing interests.

Author details: Mehedi Hasan Mandal, Assistant Professor, completed his M.Phil. from the University of Burdwan in 2017 on the dynamism of the oxbow lakes of Bhagirathi River. At present, he is engaged in assessing and enumerating the indigenous avian diversity and their ecological importance of the floodplain wetlands of Lower Ganges Basin, which has far been neglected by the locals due to ignorance. Arindam Roy is presently working as a Senior Research Scholar in the Department of Geography, the University of Burdwan. He has completed M.Sc. from the University of Calcutta in 2014 with certain expertise in environmental geography. Professor Giyasuddin Siddique has been working in the Department of Geography, the University of Burdwan, since 1999. He is keenly interested in field-based research on forests, ecology and many other contemporary environmental issues.

Author contributions: MHM, AR, and GS has collectively designed the study and collected the data/information through field investigation in different periods. MHM analyze the data and wrote the paper. AR and GS have also incorporated their inputs to improve the quality of the article. All authors read and approved the final manuscript.

Acknowledgements: The authors convey their heartfelt gratitude to the local villagers of the area, who has extended their sincere co-operation and help during the survey period. 


\section{INTRODUCTION}

Natural wetlands benefit nearby human communities and serve natural environments in various ways. Floodplain wetlands are among the most productive and species-rich lacustrine ecosystems (Kingsford et al. 2016). As an ecotone located between terrestrial and aquatic ecosystems, wetlands provide enriched habitat for numerous unique, rare, and threatened species of birds, mammals, fish, amphibians, insects, and plants (Stella et al. 2011; Garg 2015). Therefore, they are often judiciously considered as 'Ecological Hotspots' (Ward \& Stanford 1995) or 'Biological Supermarkets' (Chen \& Zhang 2001; Chen \& Lu 2003). Among the sheltered species, water birds possess an important place because of their crucial ecological roles and very useful ecosystem services to the human communities (Bibi \& Ali 2013).

The bird species directly or indirectly dependent upon the permanent or semi-permanent water bodies, either sweet or saline, for feeding, breeding and nesting may be grouped as water birds (Kumar \& Gupta 2013). As a natural ally of wetland ecosystems, water birds help sustains the ecological balance of the habitats by performing various key functions (Mistry et al. 2008; Slabbekoorm \& Ripmeester 2008). They occupy multiple trophic levels of grazing and aquatic food chain and maintain the diversity of other organisms with commensalism (Sharma \& Saini 2014). They also help in pest control, propagule dispersal, and nutrient cycling, retarding potential disease outbreaks in and around the wetlands (Green \& Elmberg 2014). Waterbirds have been one of the chief sources of feathers, meat and eggs (Krcmar et al. 2010), and they also contribute to cultural or religious values in different parts of the world (Kear 1990).

The habitat preference of birds depends upon various factors, including depth and quality of water, availability of food, nature of vegetation for shelter, degree of human intervention, and the presence of predators and inter-species competitors (Stewart 2001). Owing to their high mobility, birds react quickly to changes in habitat quality (Puri \& Virani 2016), thus they are considered to be useful bio-indicators of ecosystem integrity, quality, health and productivity (Kumar \& Gupta 2013; Mazumdar 2017). Recent worldwide loss and degradation of wetlands have conspicuously affected water birds through gradual shrinkage in the area and quality of their habitats.

India hosts diverse and unique waterbird species because of its diversity in topography and climate (Prasad et al. 2002). Several studies (Khan 2010;
Rajashekara \& Venkatesha 2010; Kumar et al. 2016; Kar \& Debata 2018) have searched out in-depth accounts of avian species (especially winter migrants) of different wetlands of the country and also endeavored to trace the impact of human intervention on their abundance, density, distribution, and composition. The floodplain wetlands aligned on both sides of river Bhagirathi over the riparian tract of the lower Gangetic plain of West Bengal are a biologically prolific and rich repository of biological diversity (Mukherjee 2008). Various ornithological works have been carried out in different water bodies interspersed over the southern portion of the Bengal delta. The ecological diversity of two oxbow lakes (floodplain wetlands), located at the southeastern part of the Ganges delta has been comprehensively studied by Khan (2002), while the diversity of waterfowl at SantragachiJheel has been studied by Mazumdar et al. (2005). Further, Mazumdar et al. (2007) also assessed and enumerated the composition and diversity of migratory waterbirds in six different wetlands, namely, Nalban Bheri, Santragachi Jheel, Saheb Badh, Bakreshwar Barrage, Tilpara Barrage, and wetlands inside Ballavpur Wildlife Sanctuary of southern West Bengal. On the other hand, Mukhopadhyay \& Mazumdar (2019) nicely presented the habitat-wise distribution of birds species in and around the lower Gangetic delta.

Despite facing immense anthropogenic pressures, these wetlands host a wide variety of 'wetland birds' species, both resident and migratory, throughout the year (Mazumdar \& Saha 2016). There is a lack of complete accounts of the biological resources of those wetlands, except for Purbashali Lake (Chupi Beel) on the right bank of the river. As a wintering site for migratory birds, Chupi has drawn attention from scholars, whereas other wetlands, including the Arpara Beel and Chariganga, have failed to do so. The composition, distribution, diversity, abundance and threats of the water birds at Purbasthai Oxbow Lake have been extensively evaluated by various studies (Ganesan \& Khan 2008; Chowdhury 2015; Ghosh 2016; Mandal 2017; Debnath et al. 2018; Mandal \& Siddique 2018; Mandal et al. 2018). The ecological and economic significance of Arpara Beel and Chariganga wetlands is thus yet to be evaluated properly. This study aims to prepare a comprehensive checklist of the water birds found in and around these wetlands, and to assess bird abundance and the effects of human interventions in their habitat. 


\section{MATERIAL AND METHODS}

\section{Study area}

Arpara Beel and Chariganga, two hook-shaped floodplain wetlands at the left bank of the river Bhagirathi in the moribund part of the Ganga Delta (Bagchi 1944) have been selected as the area under study. Given the administrative location, they are situated in the western part of Nakashipara Block of Nadia District, West Bengal (Figure 1). Given that geomorphological specificity, these wetlands are palaeochannels of river Bhagirathi and have been originated through dynamicity of lateral channel shifting with the simultaneous erosion-accretion process. Though direct connectivity with the Bhagirathi River keeps the Chariganga wetland perennial, its water cover area gets receded at dry seasons. The Arpara Beel, on the other hand, is semi-permanent since most of it dries up during summer. Delinked from the prime course of the river, this abandoned channel normally receives no inflow. Both wetlands achieve their full storage capacity only in the monsoon period, when they receive a massive influx of river water. Such spatiotemporal alterations have obvious impacts upon water birds, as well as on the availability and utility of ecosystem services offered by the lake.

\section{Methods of data collection and analysis}

Primary data on bird species in the wetlands were collected via frequent field visits and empirical observations once each month from April 2019 to March 2020. The counting process was carried out in the morning and afternoon (i.e., 0600-1000 $\mathrm{h}$ and 0400-0600 h) (Kumar \& Sharma 2019) following the point count method (Issa 2019; Volpato et al. 2009). A comprehensive checklist of the birds encompassing their common (local) name, scientific name, taxonomic position (orders, families, and species), dispersal status, habitat location, status according to the International Union for Conservation of Nature and Natural Resources (IUCN), global trends of the population, was prepared, according to the works of Praveen et al. (2016), and Issa (2019). The birds are also classified into four subgroups like Very Common (VC) (nearly 80-100 \% during field visit), Common (Co) (50-79.9\%), Fairly Common (FC) (20-49.9\%), and Rare (Ra) $(<19.9 \%)$ based on the frequency of observation (Khan \& Nahar 2009).

The relative abundance of bird species was computed with the help of the formula proposed by Torre-Cuadros et al. (2007):

$$
\mathrm{RDi}=\frac{\mathrm{n}}{\mathrm{N}} \times 100
$$

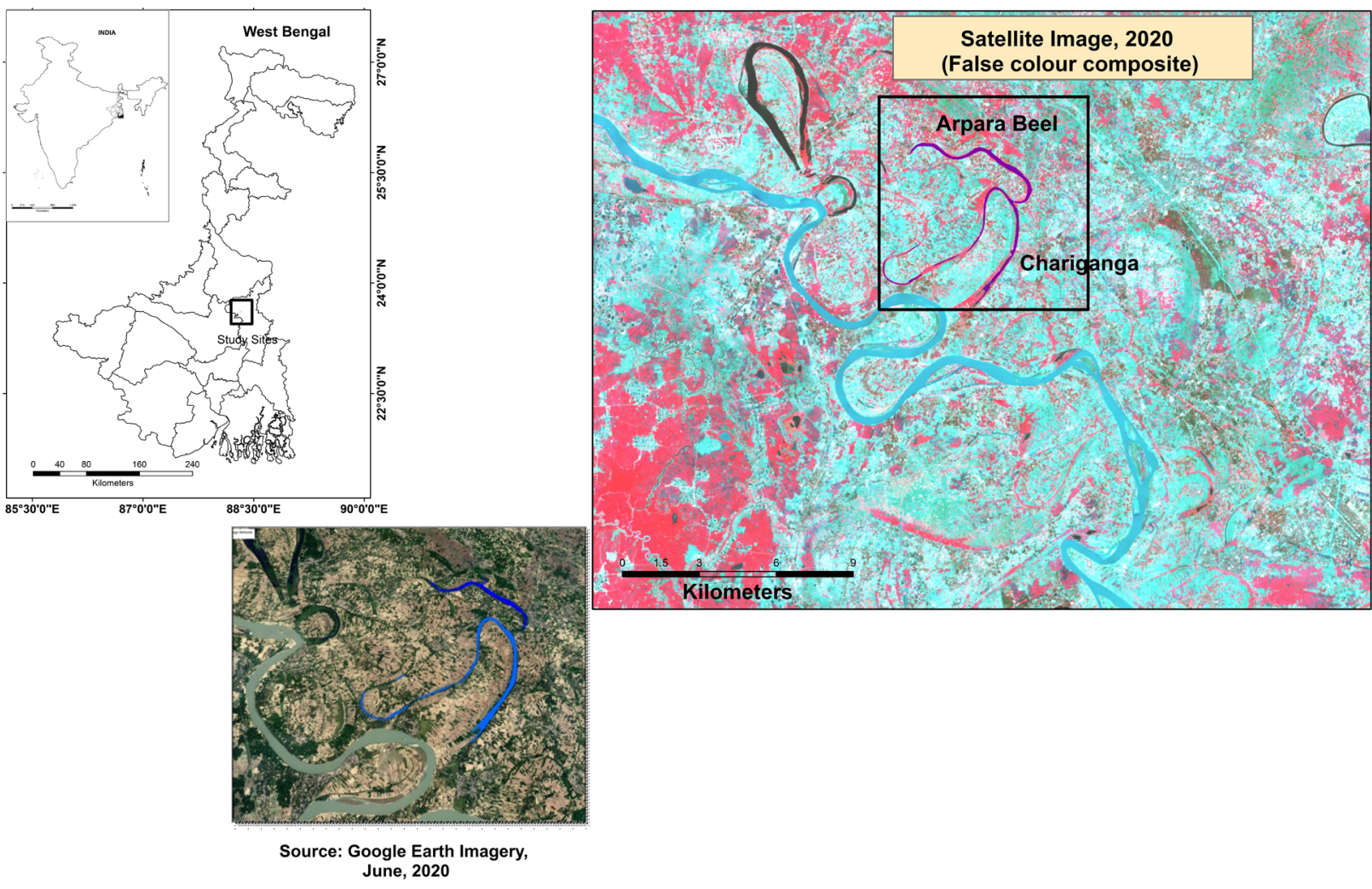

Figure 1. Location of the studied wetlands. 
Where, $\mathrm{n}=$ Total number of birds in a species, and $\mathrm{N}=$ total number of birds across all species

One way ANOVA has been employed to find out the level of seasonal variation in species richness of birds after examining the normality of data through the Shapiro-Wilk test. The entire observation period has been divided into three prominent seasons, i.e., summer or pre-monsoon (April-May), monsoon (June-October), and winter or post-monsoon (November-March) for this purpose.

Subsequently, exhaustive interviews and focus group discussions were also carried out with the nearby people who frequently use these wetlands to assess the degree of people-wetland interdependence and to identify the consequent threats towards the wetlands as a habitat of the wetland birds.

\section{RESULTS}

\section{Composition and relative abundance of water birds}

Both the selected floodplain wetlands harbour diverse species of plants (hydrophytes) and animals, especially avifauna. These sweet water storages assure ample food and adequate shelter which attract a wide variety of resident waterbird species to settle here throughout the year. Besides, they provide favorable feeding ground to the migratory bird species, especially in the winter season. A total of 37 avian species from 18 families and 11 orders were observed and documented during the survey period, though distinctive variations in species composition between these two wetlands were also documented. All 37 species are found at Chariganga, while 21 species from 14 families were sighted in Arpara Beel. Several common water birds like Little Grebe, Grey Heron, Cotton Pygmy Goose, Yellow Bittern, Indian Black Ibis, Purple Swamphen (or Western Swamphen), White-breasted Waterhen, Indian (Common) Moorhen, and Common Snipe are noticeably less in number in the concerned wetland; moreover, the surveyors couldn't find any member of avian families like Podicipedidae, Rallidae, Scolopacidae, and Hirundinidae in Arpara Beel.

A checklist comprising the order, family, local name, scientific name, dispersal status, habitat location, abundance, IUCN status (2017) and the global trend of populations of the identified bird species is tabulated in Table 1.

The relative diversity of bird families found in both the wetlands is depicted in Figure 2. It has been found that Ardeidae is the most common and abundant family (RDi value: 21.62) which comprises eight species (three types of heron, four types of egrets, and one type of bittern). Followed by Rallidae and Alcedinidae with four species each, with an RDi value of 10.81). It is noticeable that the members of the Rallidae family were not found in and around Arpara Beel. Nearly nine avian families like Podicipedidae, Charidriidae, Scolopacidae, Accipitridae, Hirundinidae, Cisticolidae, Apodidae, Pandionidae, and Meropidae having only one species each have shown the least diversity (RDi value: 2.70 ) whereas six families' (i.e., Anatidae, Ciconidae, Jacanidae, Threskiornithidae, Phalacrocoracidae, and Motacillidae) represent moderate abundance with RDi value of 5.41 (Figure 2).

\section{Status of water birds}

The water birds identified at the selected wetlands have been categorized based on four criteria: A. dispersal status, B. habitat location, C. local abundance, D. trend of the global population, and E. IUCN conservation status.

Most of the wetlands in India provide shelters to a large variety of resident birds (Mukhopadhyay \& Mazumdar 2017). The wetlands represent the same status as $3 / 4^{\text {th }}$ of the avifauna found in the area is resident. Among the 37 bird species, the number of winter migrant species are eight (21.62\%) at Chariganga and 5 (13.51\%) at Arpara Beel, whereas the three summer migrant species (8.11\%) and two (5.41\%) at Chariganga and Arpara Beel respectively. Common Snipe, Large Egret, White Wagtail, Citrine Wagtail are the common winter migrants found in the selected area. On the contrary, Lesser Whistling Duck and Cotton Pygmy-goose generally come during the summer season. Nowadays, they have even been reported in the winter season too. Besides, Egrets, Kingfishers, Pond Herons, Black-headed Ibis, Little Grebe, Bronze-winged Jacana, etc are the resident birds of the wetlands and they have frequently been seen during the field survey. The resident avian species comprises nearly $70.28 \%$ and $37.84 \%$ of the observed avifaunaat Chariganga and Arpara Beel, respectively (Figure 3).

Nearly $59.46 \%$ of bird species of Chariganga and $32.43 \%$ of Arpara Beel prefers to live in the banks of water bodies. Primarily, long-legged waders and shorebirds (like Asian Openbill, Grey Heron, Black-headed Ibis) have been found to wade in the muddy or sandy bank areas in search of food. Often, they have been observed in the adjoining paddy fields too. On contrary, almost $13.51 \%$ and $5.41 \%$ of avian species (like Lesser Whistling Duck, Cotton Pygmy-goose, Little Grebe, Indian Cormorant, and Little Cormorant), respectively, in Chariganga and Arpara Beel have been recorded in open water. Remaining birds species (like Palm Swift and various Kingfishers) generally reside in the nearby trees and shrubs, which constitute 


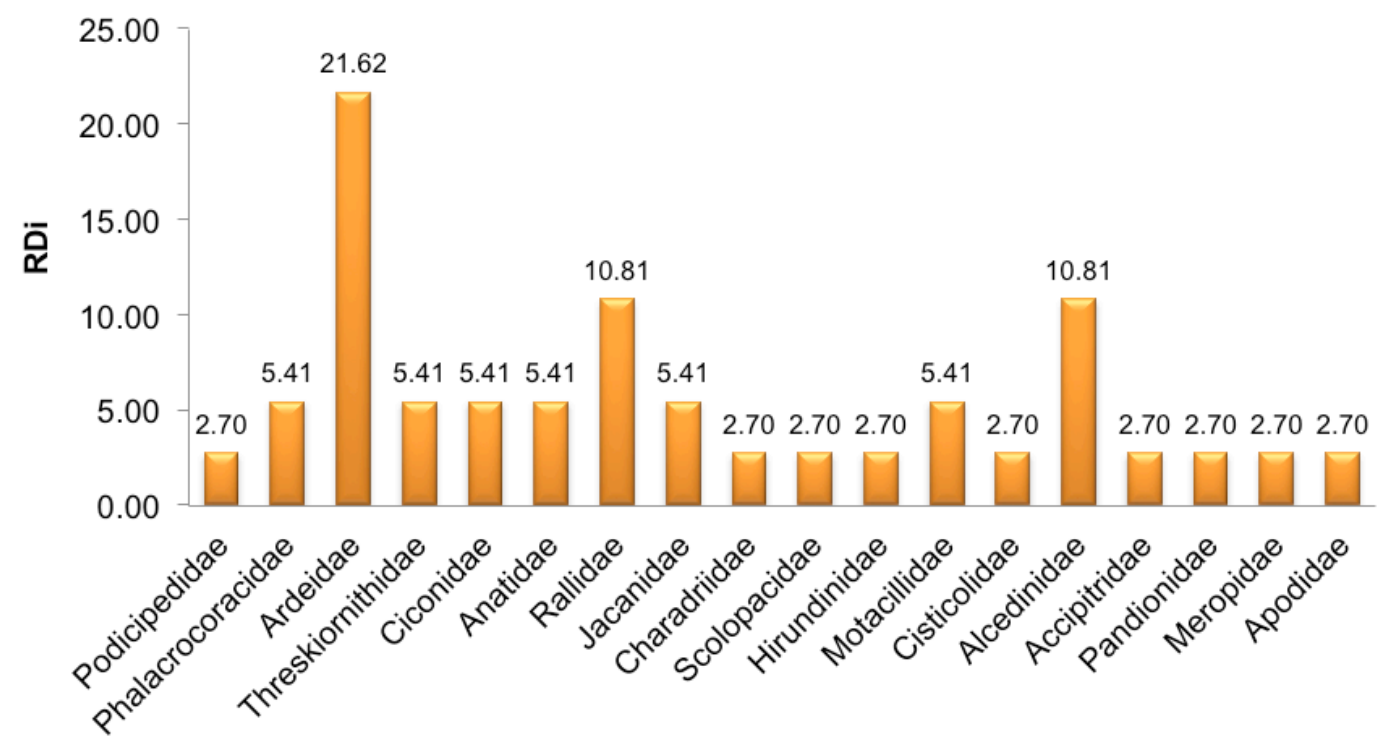

Figure 2. Relative diversity of the bird families recorded in and around Chariganga and ArparaBeel during April 2019 to March 2020.

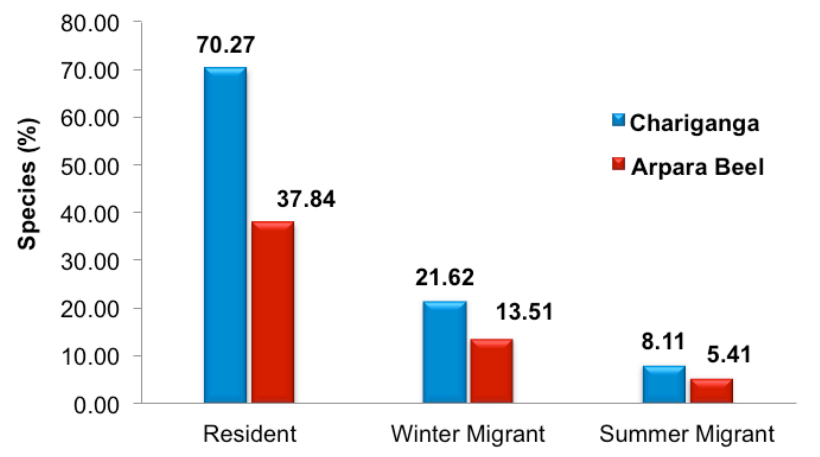

Figure 3. Dispersal Status of the wetlands' birds found in and around Chariganga and ArparaBeel during April 2019 to March 2020.

nearly $27.03 \%$ and $18.92 \%$ of identified species of the selected wetlands respectively (Figure 4).

Figure 5 shows the abundance status of recorded species. The proportion of birds in four abundance categories at Chariganga are: $30 \%$ Very Common, $13 \%$ Common, 30\% Fairly Common, and 27\% Rare. In Arpara Beel the distribution among these categories was $19 \%$, $11 \%, 11 \%$, and $16 \%$, respectively, while $43 \%$ of available birds were rarely seen during the survey.

Among recorded species $27 \%$ of birds at Chariganga and $16 \%$ at Arpara Beel have shown negative trends in global population, whereas $11 \%$ and $5.4 \%$ of birds in the wetlands have shown a positive trend worldwide. Ten species found in the area have shown a gradual decrease in their global population over the past years. Therefore, the importance of the wetlands is irrefutable as the abode of globally declining species. Further, it is worth

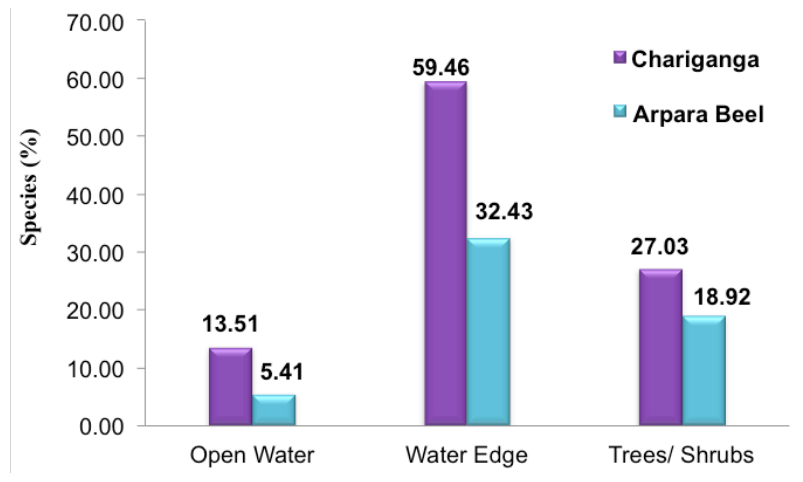

Figure 4. Habitat location of the wetlands' birds found in and around Chariganga and Arpara Beel during April 2019 to March 2020.

mentioning that the growth trends of the population are still unspecified at the global level, which is $57 \%$ and $30 \%$ of the birds at Chariganga and Arpara Beel, respectively (Figure 6).

As stated earlier, the studied wetlands harbor various unique as well as endangered avian species. One classic example is Greater Adjutant, found at both the wetlands, and which has been enlisted as Vulnerable by the IUCN in 2017. The Black-headed Ibis, fall under the Near Threatened category of IUCN (2017), which has also been observed at both of the wetlands.

\section{Temporal variation of bird species}

The acquired result of One way ANOVA has depicted highly significant variation ( $p$-value $<0.001$ at 0.05 significance level) in the seasonal species richness for both the wetlands. The month-wise variation of 
Table 1. Checklist of bird species found in and around the studied wetlands during April 2019 to March 2020.

\begin{tabular}{|c|c|c|c|c|c|c|c|c|c|c|}
\hline Order & Family & $\begin{array}{l}\text { Species/ } \\
\text { Common name }\end{array}$ & Scientific name & Chariganga & $\begin{array}{c}\text { Arpara } \\
\text { Beel }\end{array}$ & $\begin{array}{c}\text { Dispersal } \\
\text { Status }\end{array}$ & $\begin{array}{c}\text { Habitat } \\
\text { Location }\end{array}$ & $\begin{array}{l}\text { Abund- } \\
\text { ance }\end{array}$ & $\begin{array}{l}\text { IUCN } \\
\text { status }\end{array}$ & $\begin{array}{c}\text { Global } \\
\text { Population } \\
\text { Trend }\end{array}$ \\
\hline Podicipediformes & Podicipedidae & Little Grebe & $\begin{array}{l}\text { Tachybaptus } \\
\text { ruficollis }\end{array}$ & $v$ & $x$ & $\mathrm{R}$ & OW & VC & LC & $\downarrow$ \\
\hline \multirow{12}{*}{ Pelecaniformes } & \multirow[t]{2}{*}{ Phalacrocoracidae } & Indian Shag & $\begin{array}{l}\text { Phalacrocorax } \\
\text { fuscicollis }\end{array}$ & $v$ & $v$ & WM & OW & C & LC & $?$ \\
\hline & & Little Cormorant & Microcabro niger & $v$ & $x$ & $\mathrm{R}$ & ow & VC & $\mathrm{LC}$ & $?$ \\
\hline & \multirow{8}{*}{ Ardeidae } & Grey Heron & Ardea cinerea & $v$ & $x$ & $\mathrm{R}$ & WE & FC & LC & $?$ \\
\hline & & $\begin{array}{l}\text { Indian Pond } \\
\text { Heron }\end{array}$ & Ardeola grayii & $v$ & v & $\mathrm{R}$ & WE & VC & LC & $?$ \\
\hline & & Night Heron & $\begin{array}{l}\text { Nycticorax } \\
\text { nycticorax }\end{array}$ & $v$ & $v$ & $\mathrm{R}$ & WE & FC & LC & $\downarrow$ \\
\hline & & Cattle Egret & Bubulcus ibis & $v$ & $v$ & $\mathrm{R}$ & WE & VC & LC & $\uparrow$ \\
\hline & & \begin{tabular}{|l} 
Intermediate \\
Egret
\end{tabular} & Ardea intermedia & $v$ & $v$ & WM & WE & C & LC & $\downarrow$ \\
\hline & & Great Egret & Ardea alba & $v$ & $x$ & WM & WE & FC & LC & $?$ \\
\hline & & Little Egret & Egretta garzetta & $v$ & $x$ & $\mathrm{R}$ & WE & VC & LC & $\uparrow$ \\
\hline & & Yellow Bittern & Ixobrychus sinensis & $v$ & $x$ & $\mathrm{R}$ & WE & $\mathrm{FC}$ & $\mathrm{LC}$ & $?$ \\
\hline & \multirow[b]{2}{*}{ Threskiornithidae } & Indian Black Ibis & Pseudibis papillosa & $v$ & $x$ & $\mathrm{R}$ & WE & $\mathrm{R}$ & LC & $\downarrow$ \\
\hline & & Black-headed Ibis & \begin{tabular}{|l} 
Threskiornis \\
melanocephalus
\end{tabular} & $v$ & v & $\mathrm{R}$ & WE & $\mathrm{R}$ & NT & $\downarrow$ \\
\hline \multirow{2}{*}{ Ciconformes } & \multirow{2}{*}{ Ciconidae } & $\begin{array}{l}\text { Asian Openbill } \\
\text { Stork }\end{array}$ & Anastomus oscitans & $v$ & v & WM & WE & VC & LC & $?$ \\
\hline & & Lesser Adjutant & $\begin{array}{l}\text { Leptoptilos } \\
\text { javanicus }\end{array}$ & $v$ & $v$ & $\mathrm{R}$ & WE & $\mathrm{R}$ & VU & $\downarrow$ \\
\hline \multirow{2}{*}{ Anseriformes } & \multirow{2}{*}{ Anatidae } & $\begin{array}{l}\text { Cotton Pigmy- } \\
\text { goose }\end{array}$ & $\begin{array}{l}\text { Nettapus } \\
\text { coromandelianus }\end{array}$ & $v$ & $x$ & SM & ow & C & LC & $?$ \\
\hline & & $\begin{array}{l}\text { Lesser Whistling } \\
\text { Duck }\end{array}$ & $\begin{array}{l}\text { Dendrocygna } \\
\text { javanica }\end{array}$ & $v$ & $v$ & SM & OW & VC & LC & $\downarrow$ \\
\hline \multirow{4}{*}{ Gruiformes } & \multirow{4}{*}{ Rallidae } & Water Cock & Gallicrex cinerea & $v$ & $x$ & $\mathrm{R}$ & WE & FC & LC & $?$ \\
\hline & & Purple Swamphen & Porphyrio porphyrio & $v$ & $x$ & $\mathrm{R}$ & WE & $\mathrm{R}$ & LC & $?$ \\
\hline & & \begin{tabular}{|l} 
White-breasted \\
Waterhen \\
\end{tabular} & \begin{tabular}{|l} 
Amaurornis \\
phoenicurus
\end{tabular} & $v$ & $x$ & $\mathrm{R}$ & WE & FC & LC & $?$ \\
\hline & & Indian Moorhen & Gallinula chloropus & $v$ & $x$ & WM & WE & $\mathrm{R}$ & LC & $?$ \\
\hline \multirow{4}{*}{ Charadriifofmes } & \multirow{2}{*}{ Jacanidae } & $\begin{array}{l}\text { Bronze-winged } \\
\text { Jacana }\end{array}$ & Metopidius indicus & $v$ & $v$ & $\mathrm{R}$ & WE & VC & LC & $?$ \\
\hline & & $\begin{array}{l}\text { Pheasant-tailed } \\
\text { Jacana }\end{array}$ & $\begin{array}{l}\text { Hydrophasianus } \\
\text { chirurgus }\end{array}$ & $v$ & $v$ & SM & WE & C & LC & $\downarrow$ \\
\hline & Charadriidae & \begin{tabular}{|l} 
Red-wattled \\
Lapwing
\end{tabular} & Vanellus indicus & $v$ & $v$ & $\mathrm{R}$ & WE & $\mathrm{R}$ & LC & $?$ \\
\hline & Scolopacidae & Common Snipe & $\begin{array}{l}\text { Gallinago } \\
\text { gallinago }\end{array}$ & $v$ & $x$ & WM & WE & FC & LC & $?$ \\
\hline \multirow{4}{*}{ Passeriformes } & Hirundinidae & Barn Swallow & Hirundorustica & $v$ & $x$ & $\mathrm{R}$ & $\mathrm{T}$ & FC & LC & $\downarrow$ \\
\hline & \multirow{2}{*}{ Motacillidae } & White Wagtail & Motacilla alba & $v$ & $v$ & WM & WE & FC & LC & $\rightarrow$ \\
\hline & & Citrine Wagtail & Motacilla citreola & $v$ & v & WM & WE & $\mathrm{R}$ & LC & $\uparrow$ \\
\hline & Cisticolidae & Plain Prinia & Prinia inornata & $v$ & $v$ & $\mathrm{R}$ & $\mathrm{T}$ & C & $\mathrm{LC}$ & $?$ \\
\hline \multirow{4}{*}{ Coraciiformes } & \multirow{4}{*}{ Alcedinidae } & Pied Kingfisher & Ceryle rudis & $v$ & v & $\mathrm{R}$ & $\mathrm{T}$ & VC & LC & $?$ \\
\hline & & $\begin{array}{l}\text { Common } \\
\text { Kingfisher }\end{array}$ & Alcedo atthis & $v$ & v & $\mathrm{R}$ & T & VC & LC & $?$ \\
\hline & & \begin{tabular}{|l|} 
Stork-billed \\
Kingfisher \\
\end{tabular} & $\begin{array}{l}\text { Pelargopsis } \\
\text { capensis }\end{array}$ & $v$ & $x$ & $\mathrm{R}$ & $\mathrm{T}$ & $\mathrm{R}$ & LC & $\downarrow$ \\
\hline & & $\begin{array}{l}\text { White-breasted } \\
\text { kingfisher }\end{array}$ & Halcyon smyrnensis & $v$ & $x$ & $\mathrm{R}$ & $\mathrm{T}$ & VC & LC & $\uparrow$ \\
\hline \multirow{2}{*}{ Accipitriformes } & Accipitridae & Indian Shikra & Accipiter badius & $v$ & v & $\mathrm{R}$ & $\mathrm{T}$ & $\mathrm{R}$ & LC & $\rightarrow$ \\
\hline & Pandionidae & Osprey & Pandion haliaetus & $v$ & $v$ & $\mathrm{R}$ & $\mathrm{T}$ & $\mathrm{R}$ & LC & $?$ \\
\hline Coraciiformes & Meropidae & Green Bee-eater & Merops orientalis & $v$ & $v$ & $\mathrm{R}$ & $\mathrm{T}$ & $\mathrm{FC}$ & $\mathrm{LC}$ & $?$ \\
\hline Apodiformes & Apodidae & Asian Palm Swift & $\begin{array}{l}\text { Cypsiurus } \\
\text { balasiensis }\end{array}$ & $v$ & $v$ & $\mathrm{R}$ & T & FC & LC & $?$ \\
\hline
\end{tabular}

Dispersal status: R-Resident | SM-Summer Migrant | WM-Winter Migrant | Habitat Location: OW-Open Water | WE-Water Edge | T-Trees and Shrubs | Abundance: VC-Very Common | C-Common | FC-Fairly Common | R-Rare | IUCN Status: LC-Least Concern | NT-Near Threatened | VU-Vulnerable | Trend: ?-Unknown $\mid \uparrow-$ Increasing $\mid \downarrow-$ Decreasing $\mid \rightarrow-$ Stable. 


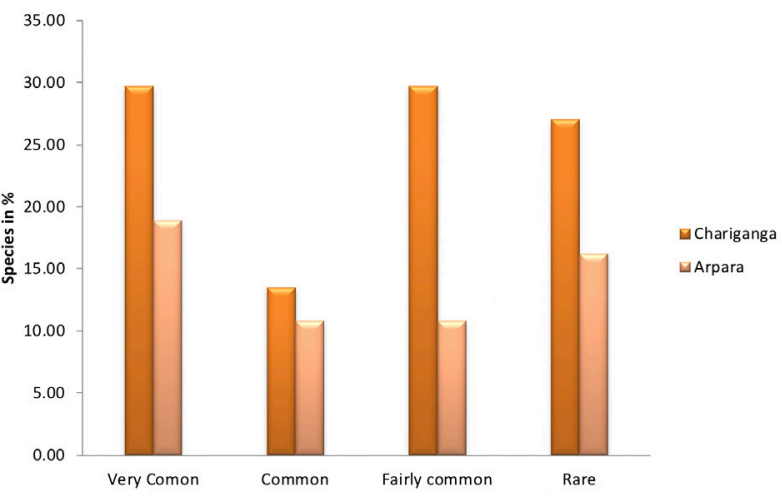

Figure 5. Local abundance status of the wetlands' birds found in and around Chariganga and Arpara Beel during April 2019 to March 2020.

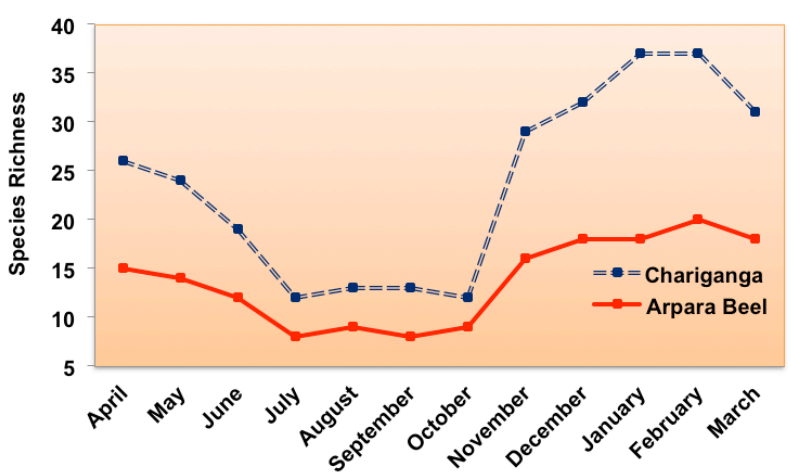

Figure 7. Month wise Variation of Species Richness of the wetlands birds found in and around Chariganga and Arpara Beel during April 2019 to March 2020.

abundance of birds species in both the wetlands has been shown in Figure 7. It reveals that the species richness of both the wetlands is comparatively higher during the winter season (November to February), which declines during the monsoon period. A mild but fair inflow of winter migratory birds naturally enhances the species affluence as well as the birds' population (Figure 8 ). The species richness in Chariganga reaches its crest $(\mathrm{N}=37)$ during January and February, whereas the least richness $(\mathrm{N}=12)$ has been recorded in July and October. Similarly, the maximum and minimum abundance of birds' species at Arpara Beel has been observed in February $(\mathrm{N}=20)$ and months of July and September $(\mathrm{N}=8)$, respectively.

\section{DISCUSSION}

The availability of food, preference of habitat location, area of food collection and wading, depth and quality of water, presence of hydrophytes, and nature

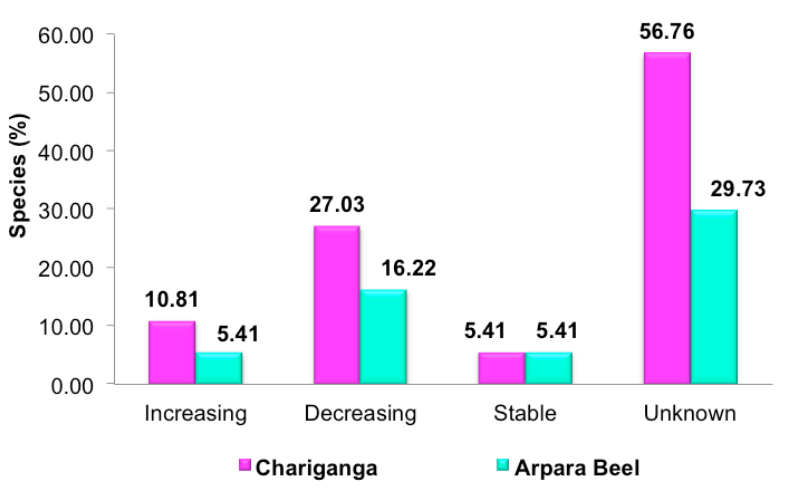

Figure 6. Global trend of population of the wetlands' birds found in and around Chariganga and Arpara Beel during April 2019 to March 2020.

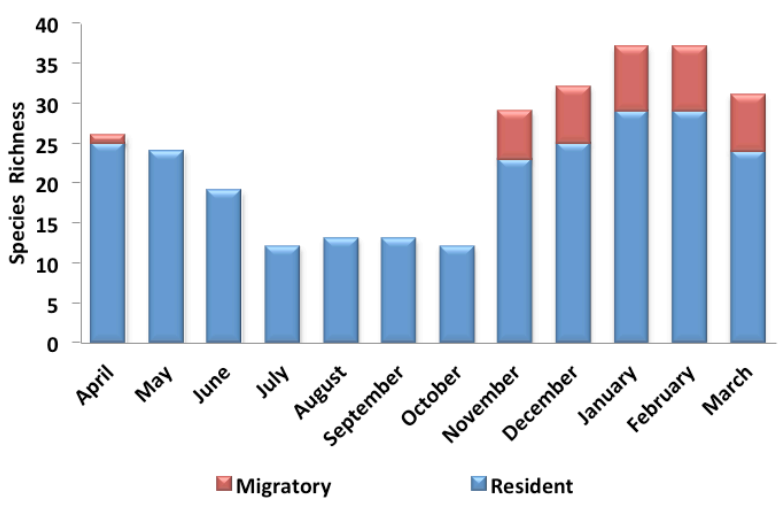

Figure 8. Influence of Winter Migrants in Species Richness of the wetlands' birds found in and around Chariganga and Arpara Beel during April 2019 to March 2020.

of the habitat have determined the temporal variation of abundance as well as species richness (Saygili et al. 2011) in and around the lakes under study. The waterfowls of the Anatidae family prefer deep, open water areas clear from submerged/floating hydrophytes (Benoit \& Askins 1999; Kumar \& Sharma 2019), while the Jacanidae family requires plenty of floating vegetation for food and shelter (Grimmet et al. 2011). Naturally, their occurrences are less and spatially more confined within the habitat. Thus the relative abundance of some birds' families, i.e., Ardeidae, Rallidae, and Alcedinidae is comparatively higher than others in both of the wetlands. Moreover, human activities adversely affect and restrict the abundance of some families like Charidriidae, Scolopacidae, Motacillidaeetc (Mandal \& Siddique 2018). The abundance of Swamphens, wagtails and waders is controlled by the availability of food at the nearby agricultural fields (Ringelman 1990). As the average depth in most parts of these wetlands decreases the availability of invertebrates increases (Murkin \& 
Kadlec 1986), which attracts various birds like egrets and herons of the Ardeidae family, for which the family has recorded its higher abundance. The abundance of Common Moorhen and White-breasted Waterhen birds of the Rallidae family is high at Chariganga because a large part of the water body is covered with dense water hyacinth, water lily, and various types of weeds that attract those birds. But, in the case of Arpara Beel, the Rallidae family is absent, as the maximum part of the wetland either contains shallow water or has been altered into the land (Image 1).

The species richness in both of the wetlands reached its maximum in the winter season due to the arrival of migratory birds. Generally, the winter migrants came into the area in November and some of the species reside here till the end of April. The following diagram (Figure 8) illustrates how the species richness gets influenced by thewinter migrants. But, the utilization of the wetlands for 'boro' (winter paddy) production significantly interrupts the arrival of migratory birds (Image 2).

The massive influx of river water and precipitation in the monsoon helps the full storage condition of the water bodies. Even the low lands, agricultural fields, and shallow surface depressions in and around the selected wetlands often get inundated under stagnant water. Thus, the habitat area of the resident bird's species has seasonally expanded due to the creation of new/ alternative living spaces. The bird's species spread over the vast areas, which has naturally reduced their density in the concerned lake areas. Therefore least species richness has been enumerated during the monsoon months (June to October). On the contrary, the majority of smaller wetlands become dried up in summer, and various birds species gather at the larger wetlands. The water areas become confined in some definite spots (portions) of the wetlands during dry spells (summer and winter) of the year. Under such peculiar circumstances, the gathering of birds' species becomes restricted near the water dots of the wetlands. During this period, summer migrants like Lesser Whistling Duck, Cotton Pygmy Goose, and Pheasant-tailed Jacanas arrive in these wetlands.

Nearly half of the world's wetlands have been lost in the 20th century, and the remaining face serious threats by anthropogenic interventions (Fraser \& Keddy 2005). Such loss and degradation have negatively affected the population and distribution of water birds, as they greatly depend upon the wetland habitats for survival (Ma et al. 2010). Since their origin, the concerned wetlands have been rapidly modified by the diverse socio-economic activities of the nearby human group.
Focus group discussions and field surveys unveil that these wetlands provide an array of ecosystem services, from provisioning material resources to intangible cultural services, which put a significant impact on the economic and cultural livelihood patterns of the local people. Mandal et al. (2020) have identified 33 ecosystem services (encompassing eight provisioning, 10 regulating, five cultural, and 11 supportive services), extended by these selected wetlands. The local people interact with the wetlands in 13 ways to collect the benefits of the ecosystem services. They have acquired various wetland products like green leafy vegetables, fish, freshwater, forage, fuel, medicinal herbs, humus, and mud. The agrarian community of the area utilizes the wetlands as chief sources of irrigation and often uses the shallow bank areas as crop fields or seedbeds. As a result the collection and extraction of wetland ecosystem services by local people adversely affect the wetlands as the habitat of water birds. But the utilization pattern has shown distinctive changes during the dry and wet spell of the year with the seasonal transformation of the lakes. Both the wetlands have turned into the rich fishing ground during monsoon days with the significant influx of water from the river Bhagirathi, while maximum portions of these two lakes become dried up during dry spells of the year. In such a situation, the local farmers have temporarily altered a considerable proportion of these wetlands into agricultural fields by encroaching and reclaiming the area of the wetlands. Such manmade seasonal transformation destroys the ecological setting of the habitat and has posed serious threats to the existence of the floral and faunal community, especially the avifauna (Image 3 ).

Over extraction of provisioning, resources have intensified the human pressure, which has diminished the suitability of those lakes as the abode of the birds. As a large part of the ArparaBeel dries up in summer, every exposed and accessible part of the wetland is used for cultivation and grazing purposes. Similarly, a significant part of the submerged bank Chariganga has now been reclaimed and is used by the locals for cropping. Even, a remarkable portion of these two wetlands has been transformed into agricultural and pastoral land perpetually and the water areas have gradually been shrunk. For example, the water cover area of Chariganga has been reduced from $1.45 \mathrm{~km}^{2}$ in 2010 to $1.05 \mathrm{~km}^{2}$ in 2020, whereas the areal coverage of Arpara Beel has been reduced from $0.69 \mathrm{~km}^{2}$ to $0.52 \mathrm{~km}^{2}$ in 2020 due to anthropogenic interventions.

Such human-induced artificial alteration of the transitional areas has damaged the ecological niche of 

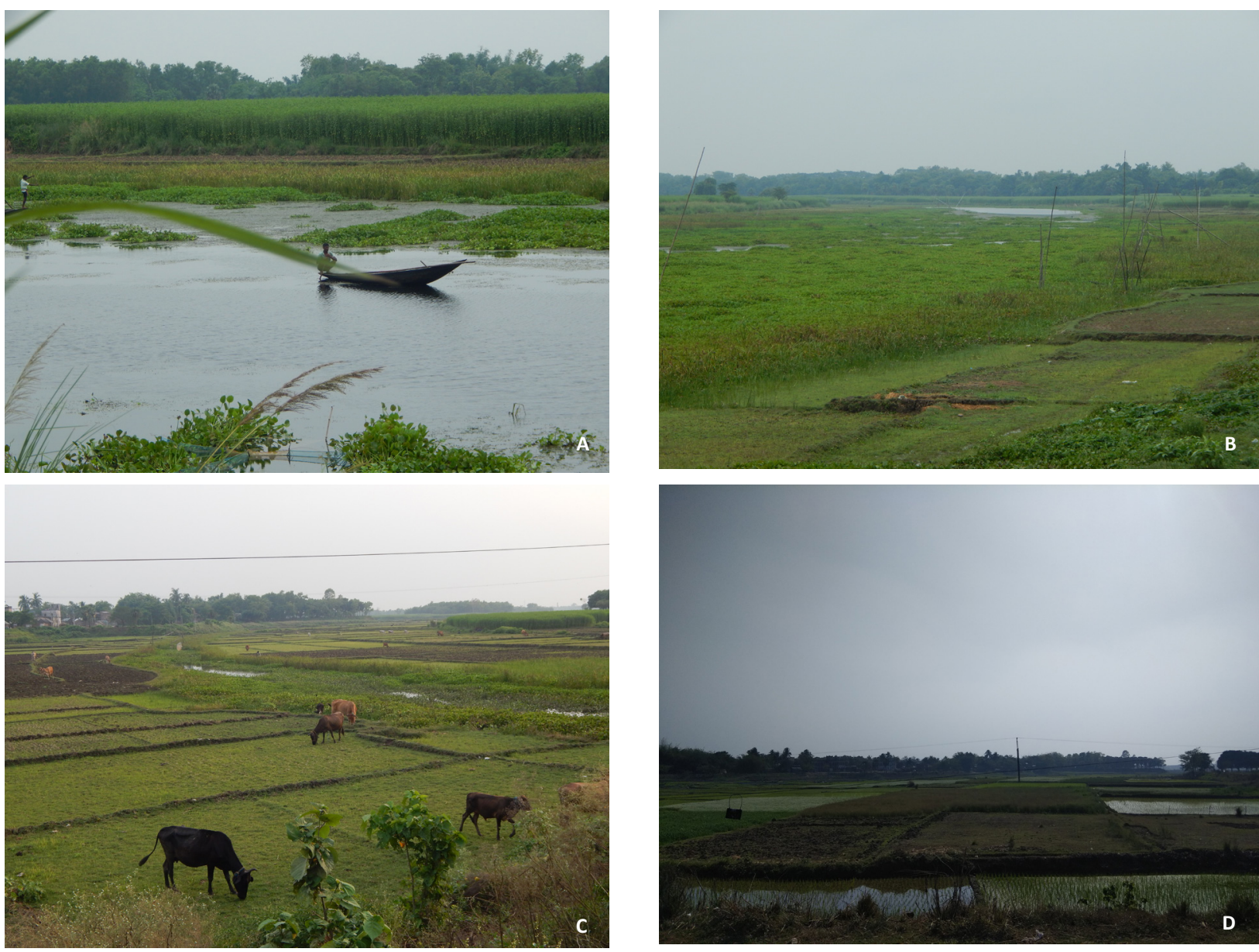

Image 1. A \& B showing habitat status of Chariganga, filled with water hyacinth and weeds, helps birds to settle, whereas C \& D showing habitat status of Arpara Beel, used as pasture land and agricultural filed. (C) Authors.

the water birds, especially of the waders. It has brought profound adverse effects on the population and species diversity of the bird community. Once, Arpara Beel served the local people with various ecosystem services. Human intervention to grab that service led to serious damage to the wetland. As a result Arpara Beel now does not produce many resources for human beings except agricultural land and pastoral ground. Moreover, it has lost its quality as a habitat of avifauna thus the species richness of waterbirds is less in comparison to Chariganga Beel. In a similar way jute retting, wetland agriculture, the transformation of parts of Chariganga as pasture land, acting as garbage disposal center, pollution from pesticides coming from surrounded crop fields, etc are major threats to Chariganga Wetland. Local people have opined that the abundance of birds has gradually declined over time in the case of Chariganga also. The numbers of diverse bird species seen in winter are also reduced in number for enhanced human intervention, compared to the earlier phases of evolution of the concerned wetland. Though species richness is higher at Chariganga, it is now under tremendous pressure of human intervention which should be controlled otherwise Chariganga wetland will be a lost habitat for water birds.

\section{CONCLUSION}

The present study highlights the importance of the two selected wetlands as a habitat of residents as well as migratory birds species. But, fragmentation of the habitat by human encroachment and pressures has threatened the existence of the local birds. Recent agricultural extension, as well as arbitrary extraction of wetland resources, is instrumental to the tremendous degradation of those wetlands, which has posed a conspicuous impact upon the size, richness, and distribution of the birds' species. Predominantly, the bank areas have now been altered into the zone of 

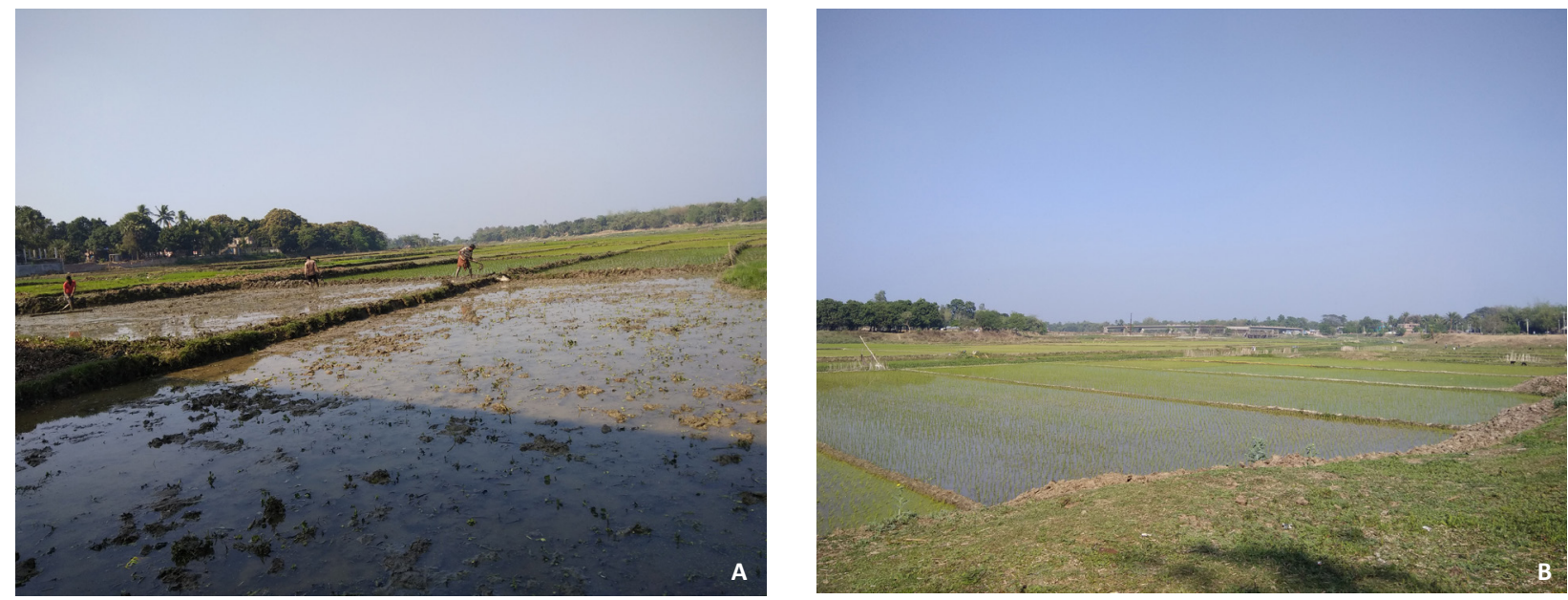

Image 2. A \& B Boro cultivation at Arpara Beel. (C) Authors.
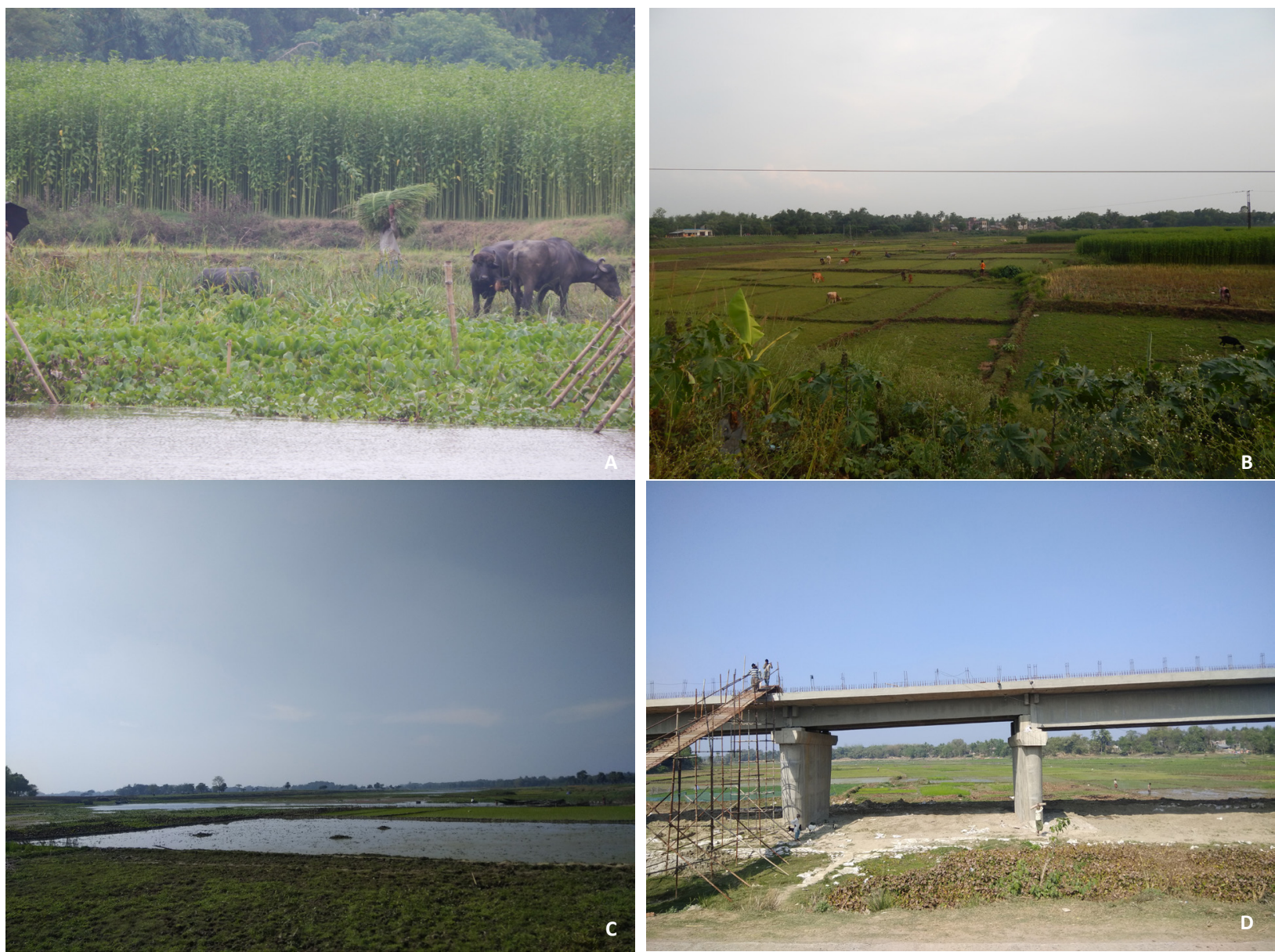

Image 3. Human encroachment and habitat alteration at both the wetlands in the dry period: A \& B Arpara Beel; C \& D Chariganga Beel. (c) Authors.

human-birds conflict. Thus the ecological setup of such areas has been disrupted which has directly been consequent upon the avian species. The importance of the resident birds in maintaining local ecological equilibrium should not be denied rather appreciated. Thus their habitat needs to be conserved essentially with a sustainable management plan that would benefit both the birds and the other stakeholders of the wetlands. 


\section{REFERENCES}

Benoit, L.K. \& R.A. Askins (1999). Impact of the spread of Phragmites on the Distribution of Birds in Connecticut Tidal Marshes. Wetlands 19(1): 194-208. https://doi.org/10.1007/BF03161749

Bibi, F. \& Z. Ali (2013). Measurement of Diversity Indices of Avian Communities at Taunsa Barrage Wildlife Sanctuary, Pakistan. The Journal of Animal \& Plant Science 23(2): 469-474.

Chen, Y.Y. \& X.G. Lu (2003). Wetland Functions and Wetland Science Research Direction. Wetland Science 1: 7-10.

Chen, Z.X. \& X.S. Zhang (2001). Value of Chinese Ecosystem Benefits Chinese Science Bulletin 45: 17-18. https://doi.org/10.1007/ BF02886190

Debnath, S., S. Biswas \& A.K. Panigrahi (2018). Present status and diversity of avian fauna in Purbasthali bird sanctuary, West Bengal, India. Agricultural Science Digest 38(2): 95-102.

Fraser, L.H. \& P.A. Keddy (2005). The World's Largest Wetlands: Ecology and Conservation. Cambridge University Press, Cambridge 500pp. https://doi.org/10.1017/CBO9780511542091

Garg, J.K. (2015). Wetland Assessment, Monitoring and Management in India using Geospatial Techniques. Journal of Environmental Management 148: 112-123. https://doi.org/10.1016/j. jenvman.2013.12.018

Green, A.J. \& J. Elmberg (2014). Ecosystem Services Provided by Water birds. Biological Reviews 89(1): 105-122. https://doi.org/10.1111/ brv.12045

Grimmet, R., C. Inskipp \& T. Inskipp (2011). Birds of the Indian Subcontinent. Oxford University Press, India, 528pp. https://doi. org/10.1007/s12595-018-0259-x

International Union for Conservation of Nature (IUCN) (2017). The IUCN Red List of Threatened Species, Vol. 1. BirdLife International, Gland, Switzerland. http://www.iucnredlist.org

Issa, M.A.A. (2019). Diversity and Abundance of Wild Birds Species' in Two Different Habitats at Sharkia Governorate, Egypt. The Journa of Basic and Applied Zoology 80(34): 1-7. https://doi.org/10.1186/ s41936-019-0103-5

Kar, T. \& S. Debata (2018). Assemblage of Waterbird Species in an Anthropogenic Zone along the Mahanadi River of Odisha, Eastern India: Implications for Management. Proceedings of the Zoologica Society 72: 355-363. https://doi.org/10.1007/s12595-018-0276-9

Kear, J. (1990). Man and Wildfowl. T \& A.D. Poyser, London

Khan, S.I. \& H. Naher (2009). Birds in Kurigram District of Bangladesh. Journal of Threatened Taxa 1(4): 245-250. https://doi.org/10.11609/ JoTT.o1698.245-50

Khan, R.A. (2002). The ecology and faunal diversity of two floodplain oxbow lakes of south-eastern West Bengal. Records of the Zoological Survey India 195: 1-57.

Khan, T.N. (2010). Temporal Changes to the Abundance and Community Structure of Migratory Water Birds in Santragachh Lake, West Bengal, and Their Relationship with Water Hyacinth Cover. Current Science 99: 1570-1577.

Kingsford, R.T., A. Basset \& L. Jackson (2016). Wetlands: Conservation's Poor Cousins. Aquatic Conservation: Marine and Freshwater Ecosystems 26: 892-916. https://doi.org/10.1002/aqc.2709

Krcmar, E., G.C. Van Kooten \& A. Chan-Mcleod (2010). Waterfowl Harvest Benefits in Northern Aboriginal Communities and Potential Climate Change Impacts, Resource Economics \& Policy Analysis Research Group, Department of Economics, University of Victoria.

Kumar, P. \& S.K. Gupta (2013). Status of Wetland Birds of Chhilchhila Wildlife Sanctuary, Haryana, India. Journal of Threatened Taxa 5(5): 3969-3976. https://doi.org/10.11609/JoTT.o3158.3969-76

Kumar, P. \& A. Sharma (2019). Wetland birds assemblages in manmade sacred ponds of Kurukshetra, India. Proceedings of the Zoological Society 72(1): 61-73. https://doi.org/10.1007/s12595018-0259-x

Kumar, P., D. Rai \& S.K. Gupta (2016). Wetland Bird Assemblage in Rural Ponds of Kurukshetra, India. Waterbirds 39: 86-98. https:// doi.org/10.1675/063.039.0111
Ma, Z., Y. Cai, B. Li, \& J. Chen (2010). Managing wetland habitats for water birds: an international perspective. Wetlands 30: 15-27. https://doi.org/10.1007/s13157-009-0001-6

Mandal, M.H. (2017). Environmental Importance of Palaeochannel: A Study on Purbasthali Oxbow Lake. Unpublished MPhil. Dissertation, Department of Geography, the University of Burdwan.

Mandal, M.H. \& G. Siddique (2018). Water Birds at Purbasthali Oxbow Lake: A Geographical Study. Researchers' World IX (Special Issue): 7-19.

Mandal, M.H., G. Siddique \& A. Roy (2018). Threats and Opportunities of Ecosystem Services: A Geographical Study of Purbasthali Oxbow Lake. Journal of Geography, Environment and Earth Science International 16(4): 1-24. https://doi.org/10.9734/ JGEESI/2018/43229

Mandal, M.H., A.K. Dey, A. Roy \& G. Siddique (2020). Ecosystem Services of Chariganga and Arpara Beels in Nadia District, West Bengal: A Geographical Enquiry. Space and Culture, India 8(2): 155167. https://doi.org/10.20896/saci.v8i2.742

Mazumdar, S. (2017). Composition of Avian Communities in a Humanmodified Wetland Okhla Bird Sanctuary, India: With Notes on Conservation Initiatives. Proceedings of the Zoological Society 72: 319-333. https://doi.org/10.1007/s12595-017-0239-6

Mazumdar, S., P. Ghosh \& G.K. Saha (2005). Diversity and behaviour of waterfowl in SantragachiJheel, West Bengal, India during winter season. Indian Birds 1: 68-69.

Mazumdar, S., K. Mookherjee \& G.K. Saha (2007). Migratory waterbirds of wetlands of southern West Bengal, India. Indian Birds 3: 42-45.

Mazumdar, S. \& G.K. Saha (2016). Wetlands in urban landscapes: problems and potentials, pp. 385-400. In: Saha, G.K. (Ed.) Wetland: crisis and options. Astral International Pvt. Ltd., New Delhi.

Mistry, J., A. Berardi \& M. Simpson (2008). Birds as indicators of Wetland Status and Change in the North Rupununi, Guyana. Biodiversity and Conservation 17(10): 2383-2409. https://doi.org/ doi:10.1007/s10531-008-9388-2

Mukherjee, S. (2008). Economic Valuation of a Wetland in West Bengal, India. International Water Management Institute (IWMI)TATA Water Policy Research Program Seventh Annual Partners' Meet 1, MPRA: 254-266.

Mukhopadhyay, S. \& S. Mazumdar (2017). Composition, Diversity and Foraging Guilds of Avifauna in a Suburban Area of Southern West Bengal, India. The Ring 39: 103-120. https://doi.org/10.1515/ring2017-0004

Mukhopadhyay, S. \& S. Mazumdar (2019). Habitat-wise composition and foraging guild of avian community in a suburban landscape of lower Gangetic plains, West Bengal, India. Biologia 74: 1001-1010. https://doi.org/10.2478/s11756-019-00226-x

Murkin, H.R. \& J.A. Kadlec (1986). Relationships between Waterfowl and Macro invertebrate densities in a northern prairie marsh. Journal of Wildlife Management 50(2): 212-217.

Prasad, S.N., T.V. Ramachandra, N. Ahalya, T. Sengupta, A. Kumar, A.K. Tiwari, V.S. Vijayan \& L. Vijayan (2002). Conservation of wetlands of India: A Review. Tropical Ecology 43: 173-186.

Praveen, J., R. Jayapal \& A. Pittie (2016). A Checklist of the Birds of India. Indian Birds 11(5-6): 113-172.

Puri, S.D. \& R.S. Virani (2016). Avifaunal Diversity from Khairbandha Lake in Gondia District, Maharashtra State, India. Bioscience Discovery 7(2): 140-146.

Rajashekara, S. \& M.G. Venkatesha (2010). The Diversity and Abundance of Water Birds in Lakes of Bangalore City, Karnataka, India. Biosystematica 4(2): 63-73.

Ringelman, J.K. (1990). Managing Agricultural Foods for Waterfowl. Waterfowl Management Handbook. Fish and Wildlife Leaflet 13.4.3. U.S. Fish and Wildlife Service, Washington.

Saygili, F., N. Yigit \& S. Bulut (2011). The Spatial and Temporal Distributions of Water Birds in Lakes Aksehir Eber and Lake Koyceigz in western Anatolia, Turkey-A Comparative Analysis. Turkish Journal of Zoology 35: 467-480. https://doi.org/10. 3906/zoo-0911-99

Sharma, K.K. \& M. Saini (2014). Commun ity Structure and Population 
Dynamics of Aquatic Avifauna of Gharana Wetland (Reserve), Jammu, India. International Research Journal of Biological Sciences 3(2): $1-8$.

Slabbekoorn H. \& E.A.P. Ripmeester (2008). Birdsong and anthropogenic noise: implications and applications for conservation. Molecular Ecology 17(1): 72-83. https://doi.org/10.1111/j.1365294X.2007.03487.x

Stella, J., M. Hayden, J. Battles, H. Piegay, S. Dufour \& A.K. Fremier (2011). The Role of Abandoned Channels as Refugia for Sustaining Pioneer Riparian Forest Ecosystems. Ecosystems 14(5): 776-790.

Stewart, R.E.Jr. (2001). Technical Aspects of Wetlands: Wetlands as Bird Habitats. National Water Summery on Wetland Resources (United States Geological Survey Water Supply Paper 2425). https:// water.usgs.gov/nwsum/WSP2425/birdhabitat.html
Torre-Cuadros, M.D.L.A.L., S. Herrando-Perez \& K.R. Young (2007). Diversity and Structure Patterns for Tropical Montane and Premontane Forests of Central Peru, with an Assessment of the Use of Higher-taxon Surrogacy. Biodiversity and Conservation 16(10): 2965-2988.

Volpato, G.H., E.V. Lopes, L.B. Mendonça, R. Boçon, M.V. Bisheimer, P.P. Serafini \& L.d. Anjos (2009). The Use of the Point Count Method for Bird Survey in the Atlantic Forest. Zoologia 26(1): 74-78.

Ward, J.V. \& J.A. Stanford (1995). Ecological connectivity in alluvial river ecosystems and its disruption by flow regulation. Regulated Rivers: Research \& Management 11: 105-119. 
Dr. John Noyes, Natural History Museum, London, UK

Dr. Albert G. Orr, Griffith University, Nathan, Australia

Dr. Sameer Padhye, Katholieke Universiteit Leuven, Belgium

Dr. Nancy van der Poorten, Toronto, Canada

Dr. Kareen Schnabel, NIWA, Wellington, New Zealand

Dr. R.M. Sharma, (Retd.) Scientist, Zoological Survey of India, Pune, India

Dr. Manju Siliwal, WILD, Coimbatore, Tamil Nadu, India

Dr. G.P. Sinha, Botanical Survey of India, Allahabad, India

Dr. K.A. Subramanian, Zoological Survey of India, New Alipore, Kolkata, India

Dr. P.M. Sureshan, Zoological Survey of India, Kozhikode, Kerala, India

Dr. R. Varatharajan, Manipur University, Imphal, Manipur, India

Dr. Eduard Vives, Museu de Ciències Naturals de Barcelona, Terrassa, Spain

Dr. James Young, Hong Kong Lepidopterists' Society, Hong Kong

Dr. R. Sundararaj, Institute of Wood Science \& Technology, Bengaluru, India

Dr. M. Nithyanandan, Environmental Department, La Ala Al Kuwait Real Estate. Co. K.S.C.,

Kuwait

Dr. Himender Bharti, Punjabi University, Punjab, India

Mr. Purnendu Roy, London, UK

Dr. Saito Motoki, The Butterfly Society of Japan, Tokyo, Japan

Dr. Sanjay Sondhi, TITLI TRUST, Kalpavriksh, Dehradun, India

Dr. Nguyen Thi Phuong Lien, Vietnam Academy of Science and Technology, Hanoi, Vietnam

Dr. Nitin Kulkarni, Tropical Research Institute, Jabalpur, India

Dr. Robin Wen Jiang Ngiam, National Parks Board, Singapore

Dr. Lional Monod, Natural History Museum of Geneva, Genève, Switzerland.

Dr. Asheesh Shivam, Nehru Gram Bharti University, Allahabad, India

Dr. Rosana Moreira da Rocha, Universidade Federal do Paraná, Curitiba, Brasi

Dr. Kurt R. Arnold, North Dakota State University, Saxony, Germany

Dr. James M. Carpenter, American Museum of Natural History, New York, USA

Dr. David M. Claborn, Missouri State University, Springfield, USA

Dr. Kareen Schnabel, Marine Biologist, Wellington, New Zealand

Dr. Amazonas Chagas Júnior, Universidade Federal de Mato Grosso, Cuiabá, Brasil

Mr. Monsoon Jyoti Gogoi, Assam University, Silchar, Assam, India

Dr. Heo Chong Chin, Universiti Teknologi MARA (UiTM), Selangor, Malaysia

Dr. R.J. Shiel, University of Adelaide, SA 5005, Australia

Dr. Siddharth Kulkarni, The George Washington University, Washington, USA

Dr. Priyadarsanan Dharma Rajan, ATREE, Bengaluru, India

Dr. Phil Alderslade, CSIRO Marine And Atmospheric Research, Hobart, Australia

Dr. John E.N. Veron, Coral Reef Research, Townsville, Australia

Dr. Daniel Whitmore, State Museum of Natural History Stuttgart, Rosenstein, Germany.

Dr. Yu-Feng Hsu, National Taiwan Normal University, Taipei City, Taiwan

Dr. Keith V. Wolfe, Antioch, California, USA

Dr. Siddharth Kulkarni, The Hormiga Lab, The George Washington University, Washington,

D.C., USA

Dr. Tomas Ditrich, Faculty of Education, University of South Bohemia in Ceske

Budejovice, Czech Republic

Dr. Mihaly Foldvari, Natural History Museum, University of Oslo, Norway

Dr. V.P. Uniyal, Wildlife Institute of India, Dehradun, Uttarakhand 248001, India

Dr. John T.D. Caleb, Zoological Survey of India, Kolkata, West Bengal, India

Dr. Priyadarsanan Dharma Rajan, Ashoka Trust for Research in Ecology and the Environment

(ATREE), Royal Enclave, Bangalore, Karnataka, India

\section{Fishes}

Dr. Neelesh Dahanukar, IISER, Pune, Maharashtra, India

Dr. Topiltzin Contreras MacBeath, Universidad Autónoma del estado de Morelos, México

Dr. Heok Hee Ng, National University of Singapore, Science Drive, Singapore

Dr. Rajeev Raghavan, St. Albert's College, Kochi, Kerala, India

Dr. Robert D. Sluka, Chiltern Gateway Project, A Rocha UK, Southall, Middlesex, UK

Dr. E. Vivekanandan, Central Marine Fisheries Research Institute, Chennai, India

Dr. Davor Zanella, University of Zagreb, Zagreb, Croatia

Dr. A. Biju Kumar, University of Kerala, Thiruvananthapuram, Kerala, India

Dr. Akhilesh K.V., ICAR-Central Marine Fisheries Research Institute, Mumbai Research

Centre, Mumbai, Maharashtra, India

Dr. J.A. Johnson, Wildlife Institute of India, Dehradun, Uttarakhand, India

Amphibians

Dr. Sushil K. Dutta, Indian Institute of Science, Bengaluru, Karnataka, India

Dr. Annemarie Ohler, Muséum national d'Histoire naturelle, Paris, France

\section{Reptiles}

Dr. Gernot Vogel, Heidelberg, Germany

Dr. Raju Vyas, Vadodara, Gujarat, India

Dr. Pritpal S. Soorae, Environment Agency, Abu Dubai, UAE.

Prof. Dr. Wayne J. Fuller, Near East University, Mersin, Turkey

Prof. Chandrashekher U. Rivonker, Goa University, Taleigao Plateau, Goa. India

Dr. S.R. Ganesh, Chennai Snake Park, Chennai, Tamil Nadu, India

Dr. Himansu Sekhar Das, Terrestrial \& Marine Biodiversity, Abu Dhabi, UAE
Birds

Dr. Hem Sagar Baral, Charles Sturt University, NSW Australia

Dr. Chris Bowden, Royal Society for the Protection of Birds, Sandy, UK

Dr. Priya Davidar, Pondicherry University, Kalapet, Puducherry, India

Dr. J.W. Duckworth, IUCN SSC, Bath, UK

Dr. Rajah Jayapal, SACON, Coimbatore, Tamil Nadu, India

Dr. Rajiv S. Kalsi, M.L.N. College, Yamuna Nagar, Haryana, India

Dr. V. Santharam, Rishi Valley Education Centre, Chittoor Dt., Andhra Pradesh, India

Dr. S. Balachandran, Bombay Natural History Society, Mumbai, India

Mr. J. Praveen, Bengaluru, India

Dr. C. Srinivasulu, Osmania University, Hyderabad, India

Dr. K.S. Gopi Sundar, International Crane Foundation, Baraboo, USA

Dr. Gombobaatar Sundev, Professor of Ornithology, Ulaanbaatar, Mongolia

Prof. Reuven Yosef, International Birding \& Research Centre, Eilat, Israel

Dr. Taej Mundkur, Wetlands International, Wageningen, The Netherlands

Dr. Carol Inskipp, Bishop Auckland Co., Durham, UK

Dr. Tim Inskipp, Bishop Auckland Co, Durham, UK

Dr. V. Gokula, National College, Tiruchirappalli, Tamil Nadu, India

Dr. Arkady Lelej, Russian Academy of Sciences, Vladivostok, Russia

Dr. Simon Dowell, Science Director, Chester Zoo, UK

Dr. Mário Gabriel Santiago dos Santos, Universidade de Trás-os-Montes e Alto Douro,

Quinta de Prados, Vila Real, Portugal

Dr. Grant Connette, Smithsonian Institution, Royal, VA, USA

Dr. M. Zafar-ul Islam, Prince Saud Al Faisal Wildlife Research Center, Taif, Saudi Arabia

Mammals

Dr. Giovanni Amori, CNR - Institute of Ecosystem Studies, Rome, Italy

Dr. Anwaruddin Chowdhury, Guwahati, India

Dr. David Mallon, Zoological Society of London, UK

Dr. Shomita Mukherjee, SACON, Coimbatore, Tamil Nadu, India

Dr. Angie Appel, Wild Cat Network, Germany

Dr. P.O. Nameer, Kerala Agricultural University, Thrissur, Kerala, India

Dr. Ian Redmond, UNEP Convention on Migratory Species, Lansdown, UK

Dr. Heidi S. Riddle, Riddle's Elephant and Wildlife Sanctuary, Arkansas, USA

Dr. Karin Schwartz, George Mason University, Fairfax, Virginia.

Dr. Lala A.K. Singh, Bhubaneswar, Orissa, India

Dr. Mewa Singh, Mysore University, Mysore, India

Dr. Paul Racey, University of Exeter, Devon, UK

Dr. Honnavalli N. Kumara, SACON, Anaikatty P.O., Coimbatore, Tamil Nadu, India

Dr. Nishith Dharaiya, HNG University, Patan, Gujarat, India

Dr. Spartaco Gippoliti, Socio Onorario Società Italiana per la Storia della Fauna "Giuseppe

Altobello", Rome, Italy

Dr. Justus Joshua, Green Future Foundation, Tiruchirapalli, Tamil Nadu, India

Dr. H. Raghuram, The American College, Madurai, Tamil Nadu, India

Dr. Paul Bates, Harison Institute, Kent, UK

Dr. Jim Sanderson, Small Wild Cat Conservation Foundation, Hartford, USA

Dr. Dan Challender, University of Kent, Canterbury, UK

Dr. David Mallon, Manchester Metropolitan University, Derbyshire, UK

Dr. Brian L. Cypher, California State University-Stanislaus, Bakersfield, CA

Dr. S.S. Talmale, Zoological Survey of India, Pune, Maharashtra, India

Prof. Karan Bahadur Shah, Budhanilakantha Municipality, Kathmandu, Nepal

Dr. Susan Cheyne, Borneo Nature Foundation International, Palangkaraja, Indonesia

Dr. Hemanta Kafley, Wildlife Sciences, Tarleton State University, Texas, USA

\section{Other Disciplines}

Dr. Aniruddha Belsare, Columbia MO 65203, USA (Veterinary)

Dr. Mandar S. Paingankar, University of Pune, Pune, Maharashtra, India (Molecular)

Dr. Jack Tordoff, Critical Ecosystem Partnership Fund, Arlington, USA (Communities)

Dr. Ulrike Streicher, University of Oregon, Eugene, USA (Veterinary)

Dr. Hari Balasubramanian, EcoAdvisors, Nova Scotia, Canada (Communities)

Dr. Rayanna Hellem Santos Bezerra, Universidade Federal de Sergipe, São Cristóvão, Brazil

Dr. Jamie R. Wood, Landcare Research, Canterbury, New Zealand

Dr. Wendy Collinson-Jonker, Endangered Wildlife Trust, Gauteng, South Africa

Dr. Rajeshkumar G. Jani, Anand Agricultural University, Anand, Gujarat, India

Dr. O.N. Tiwari, Senior Scientist, ICAR-Indian Agricultural Research Institute (IARI), New

Delhi, India

Dr. L.D. Singla, Guru Angad Dev Veterinary and Animal Sciences University, Ludhiana, India

Dr. Rupika S. Rajakaruna, University of Peradeniya, Peradeniya, Sri Lanka

Dr. Bahar Baviskar, Wild-CER, Nagpur, Maharashtra 440013, India

Reviewers 2018-2020

Due to pausity of space, the list of reviewers for $2018-2020$ is available online.

The opinions expressed by the authors do not reflect the views of the Journal of Threatened Taxa, Wildlife Information Liaison Development Society, Zoo Outreach Organization, or any of the partners. The journal, the publisher, the host, and the partners are not responsible for the accuracy of the political boundaries shown in the maps by the authors.

Journal of Threatened Taxa is indexed/abstracted in Bibliography of Systematic Mycology, Biological Abstracts, BIOSIS Previews, CAB Abstracts, EBSCO, Google Scholar, Index Copernicus, Index Fungorum, JournalSeek, National Academy of Agricultural Sciences, NewJour, OCLC WorldCat, SCOPUS, Stanford University Libraries, Virtual Library of Biology, Zoological Records.

NAAS rating (India) 5.64
Print copies of the Journal are available at cost. Write to:

The Managing Editor, JoTT,

c/o Wildlife Information Liaison Development Society,

No. 12, Thiruvannamalai Nagar, Saravanampatti - Kalapatti Road,

Saravanampatti, Coimbatore, Tamil Nadu 641035, India

ravi@threatenedtaxa.org 


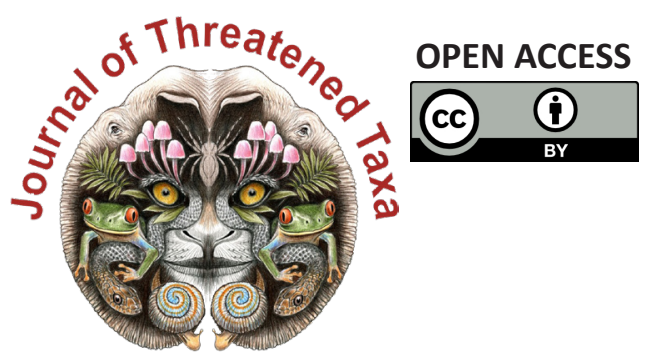

www.threatenedtaxa.org

The Journal of Threatened Taxa (JoTT) is dedicated to building evidence for conservation globally by publishing peer-reviewed articles online every month at a reasonably rapid rate at www.threatenedtaxa.org. All articles published in JoTT are registered under Creative Commons Attribution 4.0 International License unless otherwise mentioned. JoTT allows allows unrestricted use, reproduction, and distribution of articles in any medium by providing adequate credit to the author(s) and the source of publication.

ISSN 0974-7907 (Online) I ISSN $0974-7893$ (Print)

\section{November 2021 | Vol. 13 | No. 13 | Pages: 19887-20142 \\ Date of Publication: 26 November 2021 (Online \& Print) DOI: 10.11609/jott.2021.13.13.19887-20142}

\section{Article}

An inventory of geometrid moths (Lepidoptera: Geometroidea: Geometridae) of KalakadMundanthurai Tiger Reserve, India

- Geetha Iyer, Dieter Stüning \& Sanjay Sondhi, Pp. 19887-19920

\section{Communications}

Roadkills of Lowland Tapir Tapirus terrestris (Mammalia: Perissodactyla: Tapiridae) in one of its last refuges in the Atlantic Forest

- Aureo Banhos, Andressa Gatti, Marcelo Renan de Deus Santos, Leonardo Merçon,

Ilka Westermeyer, Natália Carneiro Ardente, Luis Francisco Oliveira Pereira Gonzaga, Lucas Mendes Barreto, Lucas Damásio, Tomas Lima Rocha, Vitor Roberto Schettino, Renata Valls, Helena Godoy Bergallo, Marcos Vinicius Freitas Silva, Athelson Stefanon Bittencourt, Danielle de Oliveira Moreira \& Ana Carolina Srbek-Araujo, Pp. 19921-19929

Scientific contributions and learning experiences of citizen volunteers with a small cat project in Sanjay Gandhi National Park, Mumbai, India

- Shomita Mukherjee, R. Nandini, P.V. Karunakaran \& Nayan Khanolkar, Pp. 19930-19936

Seasonal food preferences and group activity pattern of Blackbuck Antilope cervicapra (L., 1758) (Mammalia: Cetartiodactyla: Bovidae) in a semi-arid region of western Haryana, India

- Vikram Delu, Dharambir Singh, Sumit Dookia, Priya \& Kiran, Pp. 19937-19947

Studies on the habitats of Grey Francolin Francolinus pondicerianus (J.F. Gmelin, 1789) (Galliformes: Phasianidae) in northern districts of Tamil Nadu, India

- M. Pandian, Pp. 19948-19955

Recovery of vulture population in roosting and scavenging areas of Bastar and Bijapur, Chhattisgarh, India

- Sushil Kumar Dutta, Muntaz Khan, P.R.S. Nagi, Santosh Durgam \& Surabhi Dutta, Pp. 19956-19963

A geographical assessment of Chariganga and Arpara Beel (wetlands) of Nadia, West Bengal as a habitat of wetland birds

- Mehedi Hasan Mandal, Arindam Roy \& Giyasuddin Siddique, Pp. 19964-19975

Phenotypic plasticity in Barilius vagra (Hamilton, 1822) (Teleostei: Danionidae) from two geographically distinct river basins of Indian Himalaya

- Sumit Kumar, Sharali Sharma \& Deepak Singh, Pp. 19976-19984

Taxonomic notes, a new species, and a key to Indian species of the click beetle genus Cryptalaus Ôhira, 1967 (Coleoptera: Elateridae: Agrypninae)

- Harshad Parekar \& Amol Patwardhan, Pp. 19985-19999

Niche overlap of benthic macrofauna in a tropical estuary: diurnal variation

- Mário Herculano de Oliveira, Lidiane Gomes de Lima, Caroline Stefani da Silva Lima, Jéssica de Oliveira Lima Gomes, Franciely Ferreira Paiva, Graciele de Barros, Carlinda Railly Medeiros \& Joseline Molozzi, Pp. 20000-20010

Diversity of aquatic insects and biomonitoring of water quality in the upper Ganga River, a Ramsar site: a preliminary assessment

- Kritish De, Arkojyoti Sarkar, Kritika Singh, Virendra Prasad Uniyal, Jeyaraj Antony Johnson \& Syed Ainul Hussain, Pp. 20011-20018

Patterns of forest cover loss in the terrestrial Key Biodiversity Areas in the Philippines: critical habitat conservation priorities

- Bernard Peter O. Daipan, Pp. 20019-20032

The woody flora of Shettihalli Wildlife Sanctuary, central Western Ghats of Karnataka, India - A checklist

- Kanda Naveen Babu, Kurian Ayushi, Vincy K. Wilson, Narayanan Ayyappan \&

Narayanaswamy Parthasarathy, Pp. 20033-20055

Reproductive biology of Ophiorrhiza caudata C.E.C.Fisch. (Rubiaceae), an endemic and endangered creeping perennial herb of the Western Ghats, India

- Maria Theresa, Appukuttan Kamalabai Sreekala \& Jayalakshmi Mohanlal, Pp. 20056-20065
Short Communications

Successful rescue, medical management, rehabilitation, and translocation of a Red Panda Ailurus fulgens (Mammalia: Carnivora: Ailuridae) in Arunachal Pradesh, India - Jahan Ahmed, Sorang Tadap, Millo Tasser, Koj Rinya, Nekibuddin Ahmed \& Sunil Kyarong, Pp. 20066-20071

A rare photographic record of Eurasian Otter Lutra lutra with a note on its habitat from the Bhagirathi Basin, western Himalaya, India

- Ranjana Pal, Aashna Sharma, Vineet Kumar Dubey, Tapajit Bhattacharya, Jeyaraj Antony Johnson, Kuppusamy Sivakumar \& Sambandam Sathyakumar, Pp. 20072-20077

The first record of Medog Gliding Frog Rhacophorus translineatus Wu, 1977 (Anura: Rhacophoridae) from Chhukha District, Bhutan

- Sonam Lhendup \& Bal Krishna Koirala, Pp. 20078-20083

First record of a freshwater crab, Maydelliathelphusa masoniana (Henderson, 1893) (Decapoda: Brachyura: Gecarcinucidae) from West Bengal, India

- Ram Krishna Das, Pp. 20084-20089

Butterflies of Amrabad Tiger Reserve, Telangana, India

- Deepa Jaiswal, B. Bharath, M. Karuthapandi, Shrikant Jadhav, S. Prabakaran \& S. Rehanuma Sulthana, Pp. 20090-20097

An enumeration of the flowering plants of Kyongnosla Alpine Sanctuary in eastern Sikkim, India

- Sudhansu Sekhar Dash, Subhajit Lahiri \& Ashiho Asoshii Mao, Pp. 20098-20117

A new record of psychrotrophic Paecilomyces formosus (Eurotiales: Ascomycota) from India: morphological and molecular characterization

- Skarma Nonzom \& Geeta Sumbali, Pp. 20118-20123

Notes

Study on incidence and pathology of gastrointestinal parasitic infections in Nilgai Boselaphus tragocamelus in Hisar, Haryana, India

- Maneesh Sharma, B.L. Jangir, D. Lather, G.A. Chandratre, V. Nehra, K.K. Jakhar \& G. Narang, Pp. 20124-20127

An unusual vocalization of Brown Hawk-Owl Ninox scutulata (Raffles, 1822) (Aves:

Strigiformes: Strigidae) recorded from Kerala, India

- Riju P. Nair \& Shine Raj Tholkudiyil, Pp. 20128-20129

New distribution data on the genus Maripanthus Maddison, 2020 (Araneae: Salticidae) from southern India

- A. Asima, John T.D. Caleb, Dhruv A. Prajapati \& G. Prasad, Pp. 20130-20132

On the IUCN status of Boesenbergia albolutea and B. rubrolutea (Zingiberaceae) and typification of $B$. rubrolutea

- K. Aishwarya \& M. Sabu, Pp. 20133-20135

New records of mass seeding Cephalostachyum latifolium Munro (Poaceae) along the midelevation broadleaved forest of Sarpang district, Bhutan

- Jigme Tenzin, Sangay Nidup \& Dago Dorji, Pp. 20136-20139

Response

If habitat heterogeneity is effective for conservation of butterflies in urban landscapes of Delhi, India?' Unethical publication based on data manipulation

- Sanjay Keshari Das \& Rita Singh, Pp. 20140-20142

Publisher \& Host
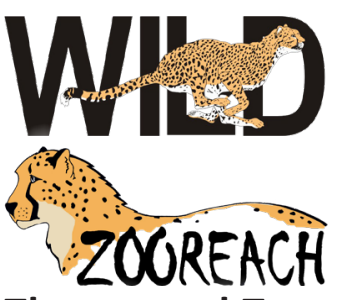

Threatened Taxa 